\section{En klassiker å bli glad i}

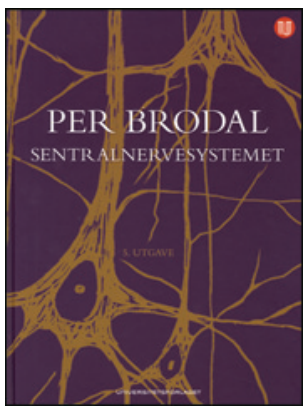

Per Brodal

Sentralnervesystemet

5. utg. 646 s, tab, ill. Oslo: Universitetsforlaget, 2013. Pris NOK 649

ISBN 978-82-15-02112-6

Per Brodals Sentralnervesystemet er en bok mange norske medisinere vil ha et forhold til. Den første utgaven kom i 1990 og var i sin tur en videreføring av den klassiske læreboken til forfatterens far, Alf Brodal, som ble utgitt første gang i 1943. Samlet har denne bokserien vært en nevroanatomisk hjørnestein for norske studenter i flere generasjoner. I engelsk utgave er far og sønn Brodals lærebøker også høyt ansett internasjonalt, noe som samtidig gjenspeiler den sterke og lange tradisjonen for nevroanatomisk forskning ved Universitetet i Oslo.

Nå foreligger Sentralnervesystemet $i$ femte utgave, fornyet og faglig oppdatert. Nevrovitenskapen er i rivende utvikling, kunnskapsgrunnlaget vokser, og det er en formidabel oppgave å skulle velge ut stoff og presentere dette på en oversiktlig måte. Ofte lages bøker om så store temaer av en sammensatt redaksjon, der flere ulike eksperter bidrar med kapitler om sine spesialområder. Men Brodal mestrer utfordringen på imponerende vis, og han viser med dette nettopp hva som kan være styrken ved å skrive som enkeltstående forfatter.

Helheten er godt ivaretatt, og hovedvekten ligger på oversikt og forståelse, snarere enn detaljer og isolerte fakta. Språket er lett, presist og velformulert. Setninger rommer tidvis fine, små doser av humor og smittende entusiasme for faget, samtidig som tonen preges av ydmykhet overfor hjernens kompleksitet og vitenskapens skiftende sannheter.

Oppdelingen i kapitler er omarbeidet i denne utgaven. Den gjør det lett å orientere seg og lese i den rekkefølgen man ønsker, uten å miste oversikten. En del fordypende stoff er skilt ut i rammer, og det er rikelig med figurer og illustrasjoner, i tillegg til en omfattende litteraturliste.

Boken er i første rekke beregnet på studenter og kan leses uten større forkunnskaper om nervesystemet. Mange vil nok likevel kunne oppleve dette som en massiv murstein ved første møte, og først bli fortrolig med stoffet når lesingen kombineres med forelesninger og studier av preparater. På den annen side er boken dyptpløyende nok til å være en verdifull grunnbok også for dem som jobber spesielt med nevrofag.

Trenger vi så lærebøker på norsk? Alle som arbeider med faget vårt, må likevel kunne lese faglitteratur på engelsk. For mange lesere vil imidlertid en tekst på vårt eget språk lette forståelsen av det kompliserte stoffet. Mange anatomiske begreper er dessuten «reverserte» på engelsk, mens det i norske fagmiljøer fortsatt er kultur for å bruke den latinske varianten, for eksempel gyrus postcentralis, snarere enn postcentral gyrus. Dette kan gjøre det ekstra tungt å lese engelsk når slike navn forekommer hyppig i teksten.

Denne nye utgaven er et imponerende stykke arbeid. Per Brodal har skrevet en nevroanatomisk klassiker, en bok å bli glad i og et verk norsk medisin kan være stolt av å ha på sitt eget fagspråk.

\section{Allmennmedisin til jubel og glede}

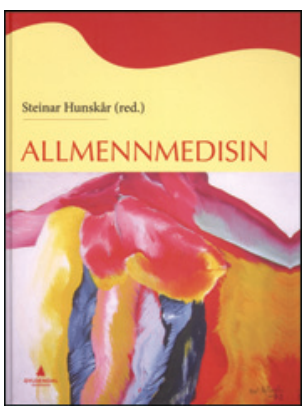

Steinar Hunskår, red.

3. utg. 984 s, tab, ill. Oslo: Gyldendal

Akademisk, 2013. Pris NOK 995

ISBN 978-82-05-40192-1

Målgruppen er medisinstudenter og allmennleger i klinisk praksis. For studentene vil den fungere som en lærebok i grunnutdanningen. Layouten i denne tredje utgaven er ny, og boken fremstår som gjennomført og moderne, men også nøktern slik at den er behagelig å bruke.

Det er seks deler. I første del beskriver forfatterne førstelinjetjenestens rolle og muligheter og begrensninger i allmennmedisin. Så følger en velskrevet del om viktige organovergripende symptomer. Videre får vi en mer tradisjonell oversikt over hvert organsystem, hvor hvert kapittel forbilledlig er delt inn i sykehistorie og klinisk undersøkelse, fulgt av en problembasert beskrivelse av de vanligste kontaktårsakene, symptomene og tegnene, før man går over på den mer «oppsummerende» delen om de forskjellige sykdommene. Avslutningsvis er det en del om problemstillinger i ulike deler av livsløpet, en del om ulike typer konsultasjoner og helt til sist en del om det å være allmennlege.

Allmennmedisin er pedagogisk, fint oppbygd og lett å bruke. Den fremstår oppdatert i forhold til klinisk praksis beskrevet i digitale informasjonskilder og artikler i Tidsskriftet, og det faglige innholdet sammenfaller godt med de prinsippene vi lærer i grunnutdanningen. Basert på dette vil den være et godt oppslagsverk også for praktiserende leger i allmennmedisin. Jeg er positivt overrasket over hvor bred dekningen er, uten at det går på bekostning av kvaliteten. For å få fullt utbytte av den fagtunge delen om tilstander og sykdommer, mener jeg imidlertid leseren må ha en del grunnleggende kunnskaper om, og forståelse av, hvert enkelt organsystem.

Utover sykdomsbeskrivelser gir boken noe som er enda viktigerenemlig et godt overblikk over vanlige problemstillinger i allmennpraksis. Denne store oversikten formidles vanskelig gjennom spredte forelesninger som berører allmennmedisinske temaer. Jeg setter stor pris på det symptomorienterte, problembaserte søkelyset. Vi lærer å tenke bredt og se pasienten i et større bilde, noe som ellers er vanskelig å få med seg i den hektiske grunnutdanningen, der vi hopper fra fag til fag og blir presentert for ulike sykdommers særtrekk. Det som gjør boken enda mer verdifull, er at den fungerer som en nærmest fullkommen praksisveileder i allmennmedisin. Forfatterne forklarer utførlig om allmennlegens rolle, ulike typer konsultasjoner, når man bør henvise og viktige små og store problemstillinger i allmennmedisinen.

Manglene er få, men jeg savner flere figurer, spesielt i kapitlet om hudsykdommer. I tillegg hadde jeg gjerne sett et avsnitt med en systematisk gjennomgang av klinisk beslutningslære.

Jeg vil anbefale mine medstudenter å kjøpe boken, også de som er ferske. Dette er en bok man kan ha med seg og ha glede av gjennom hele studietiden. Boken fungerer glimrende som oppslagsverk, men er skrevet så godt at man kan lese store deler sammenhengende. Jeg synes forfatterne klarer å formidle det særegne og fascinerende ved allmennmedisinfaget, og jeg kan ikke få rost den problembaserte formen nok.

Det er ikke ofte jeg føler jeg at en lærebok gir så mye som denne når det gjelder oversikt og supplerende informasjon i forhold til det som blir undervist, og det man kan finne på Internett. Vi er heldige som har en så grundig og gjennomført bok på norsk, hvor man beskriver norske forhold, med norske lover og regler. Det vil jeg takke forfatterne for. 